\title{
Effects of Chemical Mutagens on the Physio-Chemical Traits of Tomato
}

\author{
L. Tripathy ${ }^{1}$, S.K. Dash ${ }^{2}$ and S.R. Pradhan ${ }^{3 *}$ \\ ${ }^{1}$ College of Forestry, OUAT, Bhubaneswar-751003, India \\ ${ }^{2}$ Vegetable Agronomist, AICRP (VC), OUAT, Bhubaneswar-751003, India \\ ${ }^{3}$ Department of Vegetable Science, OUAT, Bhubaneswar-751003, India \\ *Corresponding author
}

\begin{tabular}{|c|c|}
\hline & A B S T R A C T \\
\hline & \multirow{6}{*}{ 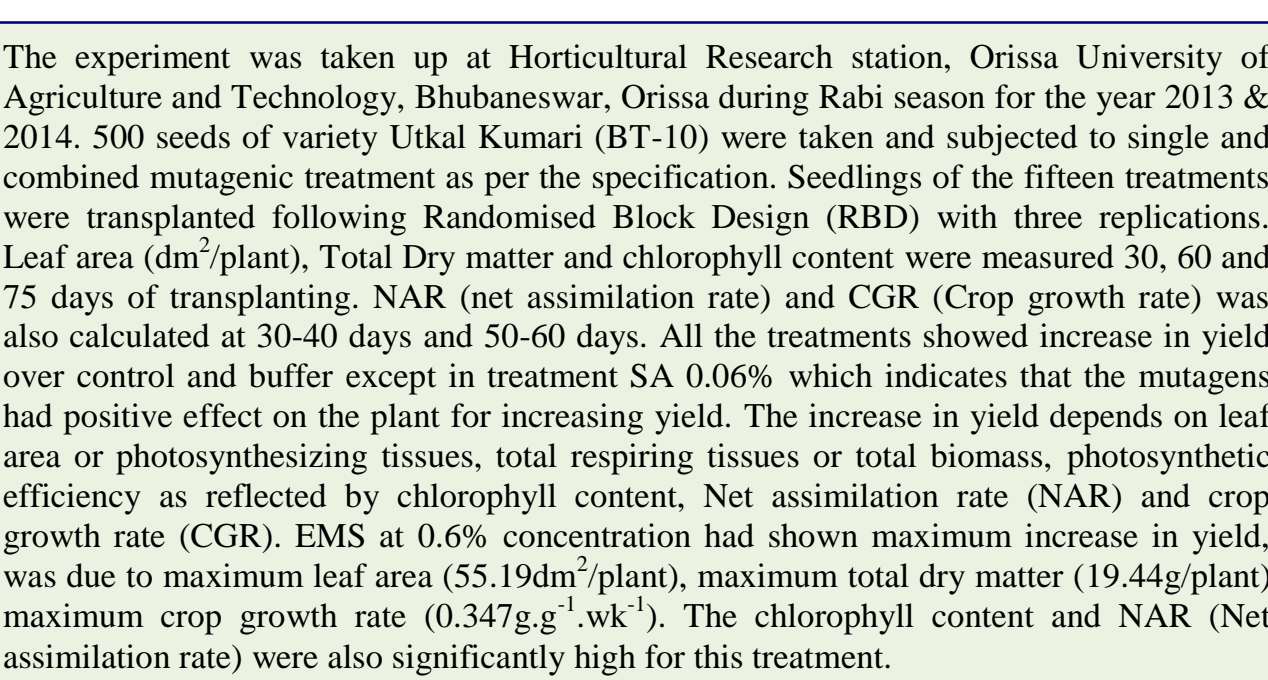 } \\
\hline Keywords & \\
\hline $\begin{array}{l}\text { Chemical mutagens, } \\
\text { Physio-chemical } \\
\text { traits, Tomato }\end{array}$ & \\
\hline Article Info & \\
\hline $\begin{array}{l}\text { Accepted: } \\
\text { 04 March } 2018 \\
\text { Available Online: } \\
10 \text { April } 2018\end{array}$ & \\
\hline & \\
\hline
\end{tabular}

\section{Introduction}

Among vegetables it is needless to emphasise the precious nature of tomato (Lycopersicon esculentum Mill.) commonly cultivated in our country. Like potato from Peru, tomato from America has been thoroughly acclimatized and domesticated to Indian Agrarian practices and crop husbandry. Increasing health conscious population of our country have found tomato as a chief source of lycopene and Ascorbic acid (Vitamin-C) thus necessitates its use as part of the daily diet.
But limitations in cultivation of tomato are still prevalent. Many breeding programmes have been taken up for the improvement of the crop. Genetic manipulation through gene pyramiding is often met with difficulty and ultimately when succeeds a new genotype is born with change in many other characters. Therefore, an alternative approach is no other than mutation breeding. The creation of genetic variability by physical and chemical mutagens presents the plant breeder a greater opportunity of selecting beneficial mutants from mutant population. The discovery of 
chemical mutagens during the Second World War was another milestone in the history of induced mutation. Since then, many chemicals have been screened and found to induce mutations. Thus the present study was done to know the effect of chemical mutagens alone and in combination on the Physio chemical traits attributing to yield in tomato.

\section{Materials and Methods}

The experiment was taken up at Horticultural Research station, Orissa University of Agriculture and Technology, Bhubaneswar, Orissa during Rabi season for the year 2013 and 2014. The variety selected for this experiment was Utkal Kumari (BT-10). For each treatment 500 healthy seeds (moisture content $11.5 \%$ ) were soaked in distilled water for 8 hours at room temperature $\left(15^{\circ}\right.$ to $\left.28^{\circ} \mathrm{C}\right)$. The soaked seeds wrapped in blotting paper for complete drying were subjected to single and combined mutagenic treatment as per the specifications depicted in the Table 1.

In combined mutagenic treatment, the materials were treated by the first chemical followed by thorough washing and again treated with the second chemical for the period as specified in the Table 1.

There were two controls, one treated with Phosphate Buffer Solution at $\mathrm{pH}-3$ and the other with distilled water. The mutagenic treatments were given in closed Petri dishes with $50 \mathrm{ml}$. solution in each. The treatments were carried out under controlled temperature $\left(20+1{ }^{\circ} \mathrm{C}\right)$ in B.O.D. incubator. The seed samples after treatments were thoroughly washed in running tap water for 1-2 minutes and seeded in the nursery bed.

Seedlings of the fifteen treatments were transplanted following Randomised Block Design (RBD) with three replications of plot size of 36.5 Sq.m. A spacing of $60 \mathrm{~cm}$ plant to plant and $75 \mathrm{~cm}$ row to row was given which accommodated 50 plants in total in a plot. The fertilizer dose was $100 \mathrm{~kg} \mathrm{~N}, 60 \mathrm{~kg} \mathrm{P}$ and $60 \mathrm{~K}$ $\mathrm{kg} / \mathrm{ha}$ followed by scheduled cultural management practices and plant protection measures taken.

Leaf area $\left(\mathrm{dm}^{2} /\right.$ plant $)$ was measured in Systronics leaf area meter at 30, 60 and 75 days of transplanting. NAR (net assimilation rate) and CGR (Crop growth rate) was also calculated as per this formula:

$\mathrm{NAR}=\left(\mathrm{W}_{2} \mathrm{P}-\mathrm{W}_{1} \mathrm{P} / \mathrm{T}_{2}-\mathrm{T}_{1}\right) \mathrm{X}\left(\ln \mathrm{A}_{2}-\ln \mathrm{A}_{1} /\right.$ $\left.\mathrm{A}_{2}-\mathrm{A}_{1}\right) \mathrm{g} \cdot \mathrm{cm}^{-2} \cdot \mathrm{wk}^{-1}$

Where, $\mathrm{W}=$ dry weight, $\mathrm{P}=$ plant, $\mathrm{T}=$ time and $\mathrm{A}=$ area

$\mathrm{CGR}=\frac{\ln \mathrm{W}_{2} \mathrm{P}-\ln \mathrm{W}_{1} \mathrm{P}}{\mathrm{T}_{2}-\mathrm{T}_{1}}$

Where $\mathrm{w}=$ dry weight, $\mathrm{P}=\mathrm{Plant}$ and $\mathrm{T}=$ time (Dash et al., 1997)

NAR and CGR were calculated at 30, 45 and 60 days of transplanting. Total dry matter of the whole plant was measured after oven drying at $60{ }^{\circ} \mathrm{C}$ for 48 hours at 30,60 and 75 days of transplanting. Total chlorophyll content of leaf was estimated by acetone extraction method (Arnon, 1949) at 30, 60 and 75 days of transplanting. Total yield of the plant was also recorded. The data was collected and pooled over for two seasons and put to statistical analysis as per SPSS software packages.

\section{Results and Discussion}

A careful analysis of the yield data revealed that all the treatments showed increase in yield over the buffer and control except in treatment SA $0.06 \%$ (Average percentage increase in yield over control $=-24.57)$. The percentage 
increase in yield of treatments over control and buffer is represented in Table 2. Treatment EMS $0.6 \%$ has recorded the maximum average percentage of increase in yield over control and buffer (105.45) followed by EMS $0.2 \%$ (60.51) and EMS $0.4 \%$ (65.32).

The increase in yield depends on leaf area or photosynthesizing tissues, total respiring tissues or total biomass, photosynthetic efficiency as reflected by chlorophyll content, Net assimilation rate (NAR) and crop growth rate (CGR) as presented in Table 3. All the characters exhibited significant difference among themselves (Fig. 1).

It was observed that EMS at $0.6 \%$ concentration had shown maximum increase in yield, was due to maximum leaf area $\left(55.19 \mathrm{dm}^{2} /\right.$ plant $)$, maximum total dry matter (19.44g/plant) maximum crop growth rate $\left(0.347 \mathrm{~g} \cdot \mathrm{g}^{-1} \cdot \mathrm{wk}^{-1}\right)$. The chlorophyll content and NAR (Net assimilation rate) were also significantly high for this treatment.

Treatments, which exhibited minimum, yield SA $0.06 \%$. This treatment also recorded minimum Net assimilation rate NAR $\left(0.038 \mathrm{~g} \cdot \mathrm{cm}^{-2} \cdot \mathrm{wk}^{-1}\right)$. These two observations suggest that all these contribute to increase in yield, which corroborates the finding of Augustine et al., (1975), Bhatt et al., (1988) and Akita et al., (1990).

It was also observed that the mutagenic treatments have influenced the leaf area. EMS has influenced the leaf area considerably in all the concentration $(0.2 \%, 0.4 \% \& 0.6 \%)$ alone or in combination at $0.4 \% \mathrm{EMS}+0.04 \% \mathrm{MH}$. The results were found to be at par as a rule at different time interval, leaf area has shown its growth indicating the increase of photosynthesizing tissue.

Fig.1 Diagram depicting the $\%$ increase in yield of tomato pooled over Two years over buffer and control

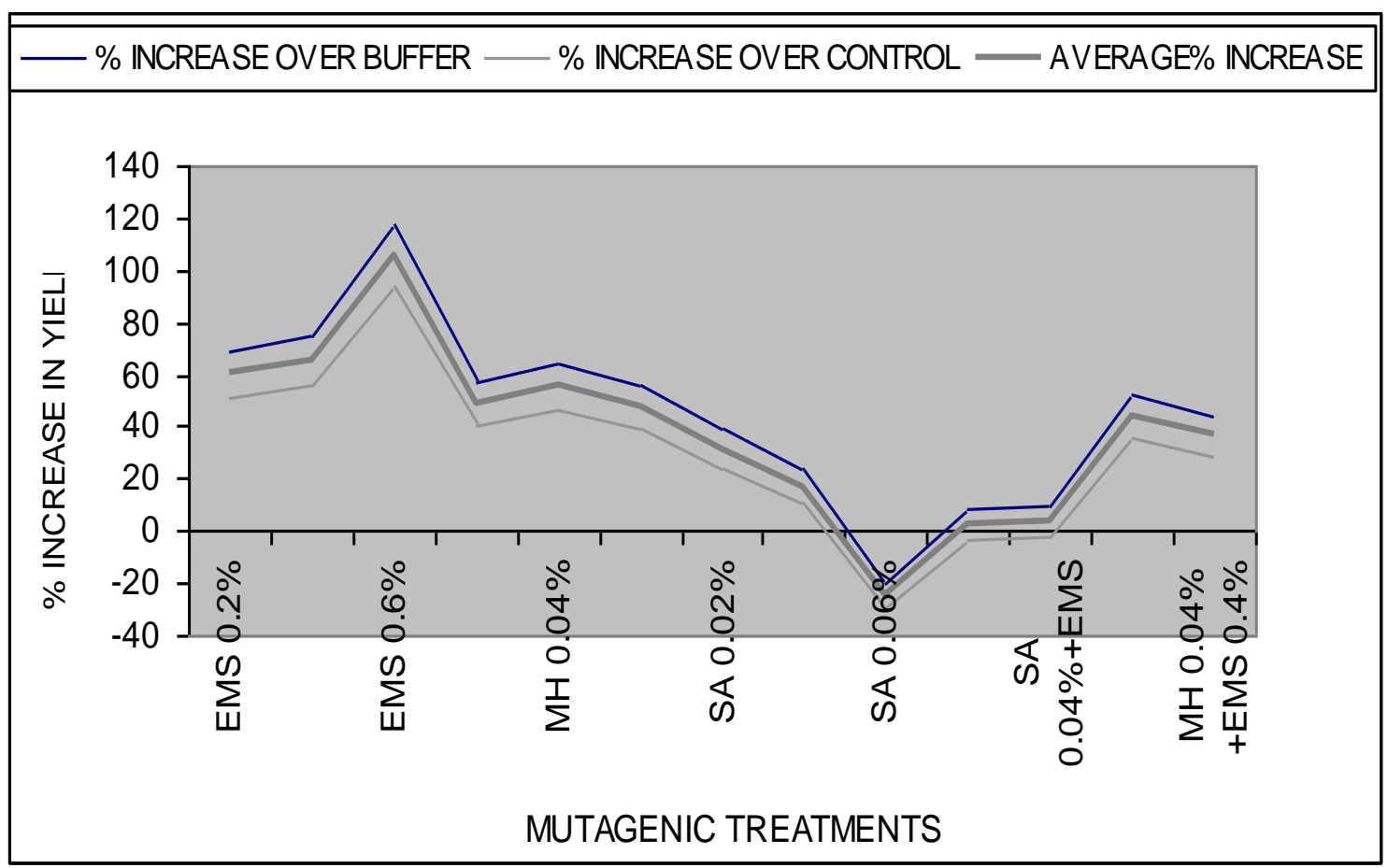

Buffer $=0.59 \mathrm{Kg} / \mathrm{Plant}$; Control $=0.66 \mathrm{Kg} / \mathrm{Plant}$ 
Table.1 Details of mutagenic treatments (mutagens, concentration and duration of treatment)

\begin{tabular}{|c|c|c|}
\hline Treatment & Mutagenic Treatment (in hrs.) & No. of Treatments \\
\hline$T_{1}=\operatorname{EMS}(0.2 \%)$ & 8 & (I) \\
\hline$T_{2}=\operatorname{EMS}(0.4 \%)$ & 8 & (I) \\
\hline $\mathrm{T}_{3}=\mathrm{EMS}(0.6 \%)$ & 8 & (I) \\
\hline $\mathrm{T}_{4}=\mathrm{MH}(0.02 \%)$ & 8 & (I) \\
\hline $\mathrm{T}_{5}=\mathrm{MH}(0.04 \%)$ & 8 & (I) \\
\hline $\mathrm{T}_{6}=\mathrm{MH}(0.06 \%)$ & 8 & (I) \\
\hline $\mathrm{T}_{7}=\mathrm{SA}(0.02 \%)$ & 8 & (I) \\
\hline $\mathrm{T}_{8}=\mathrm{SA}(0.04 \%)$ & 8 & (I) \\
\hline $\mathrm{T}_{9}=\mathrm{SA}(0.06 \%)$ & 8 & (I) \\
\hline $\begin{array}{l}\mathrm{T}_{10}=\operatorname{EMS}(0.4 \%) \\
+ \text { SA }(0.04 \%)\end{array}$ & $\begin{array}{l}4 \\
4\end{array}$ & $\begin{array}{l}\text { (I) } \\
\text { (II) }\end{array}$ \\
\hline $\begin{array}{l}T_{11}=\text { SA }(0.04 \%) \\
+\operatorname{EMS}(0.4 \%)\end{array}$ & $\begin{array}{l}4 \\
4\end{array}$ & $\begin{array}{l}\text { (I) } \\
\text { (II) }\end{array}$ \\
\hline $\begin{array}{l}T_{12}=\operatorname{EMS}(0.4 \%) \\
+\mathrm{MH}(0.04 \%)\end{array}$ & $\begin{array}{l}4 \\
4\end{array}$ & $\begin{array}{l}\text { (I) } \\
\text { (II) }\end{array}$ \\
\hline $\begin{array}{l}\mathrm{T}_{13}=\mathrm{MH}(0.04 \%) \\
+\operatorname{EMS}(0.4 \%) \\
\end{array}$ & $\begin{array}{l}4 \\
4\end{array}$ & $\begin{array}{l}\text { (I) } \\
\text { (II) }\end{array}$ \\
\hline $\mathrm{T}_{14}=$ Phosphate Buffer pH 3 & 8 & (I) \\
\hline $\mathrm{T}_{15}=$ Control (Distilled water) & 8 & (I) \\
\hline
\end{tabular}

Table.2 Total yield of the tomato pooled over two years when treated with chemical mutagens and its percentage increase over buffer and control

\begin{tabular}{|c|c|c|c|c|c|}
\hline \multirow[t]{2}{*}{$\begin{array}{l}\text { Sl } \\
\text { No. }\end{array}$} & \multirow[t]{2}{*}{ Treatments } & \multirow{2}{*}{$\begin{array}{c}\text { Yield per } \\
\text { plant } \\
(\mathrm{Kg})\end{array}$} & \multicolumn{2}{|c|}{$\begin{array}{l}\text { Percentage increase in } \\
\text { yield over control }\end{array}$} & \multirow[t]{2}{*}{$\begin{array}{c}\text { Average } \\
(\%)\end{array}$} \\
\hline & & & Buffer & Control & \\
\hline 1. & EMS $0.2 \%$ & 1.00 & 69.49 & 51.52 & 60.51 \\
\hline 2. & EMS $0.4 \%$ & 1.03 & 74.58 & 56.06 & 65.32 \\
\hline 3. & EMS $0.6 \%$ & 1.28 & 116.95 & 93.94 & 105.45 \\
\hline 4. & MH $0.02 \%$ & 0.93 & 57.63 & 40.91 & 49.27 \\
\hline 5. & MH $0.04 \%$ & 0.97 & 64.41 & 46.97 & 55.69 \\
\hline 6. & MH $0.06 \%$ & 0.92 & 55.93 & 39.39 & 47.66 \\
\hline 7. & SA $0.02 \%$ & 0.82 & 38.98 & 24.24 & 31.61 \\
\hline 8. & SA $0.04 \%$ & 0.73 & 23.73 & 10.61 & 17.17 \\
\hline 9. & SA $0.06 \%$ & 0.47 & -20.34 & -28.79 & -24.57 \\
\hline 10. & EMS $0.4 \%+$ SA $0.04 \%$ & 0.64 & 8.47 & -3.03 & 2.72 \\
\hline 11. & SA $0.04 \%+$ EMS $0.4 \%$ & 0.65 & 10.17 & -1.52 & 4.33 \\
\hline 12. & EMS $0.4 \%+\mathrm{MH} 0.04 \%$ & 0.90 & 52.54 & 36.36 & 44.45 \\
\hline 13. & MH $0.04 \%$ +EMS $0.4 \%$ & 0.85 & 44.07 & 28.79 & 36.43 \\
\hline
\end{tabular}

Buffer $=0.59 \mathrm{Kg} /$ Plant; Control $=0.66 \mathrm{Kg} / \mathrm{Plant}$ 
Table.3 Depicting the physiochemical traits pooled over two years after treatment with chemical mutagens

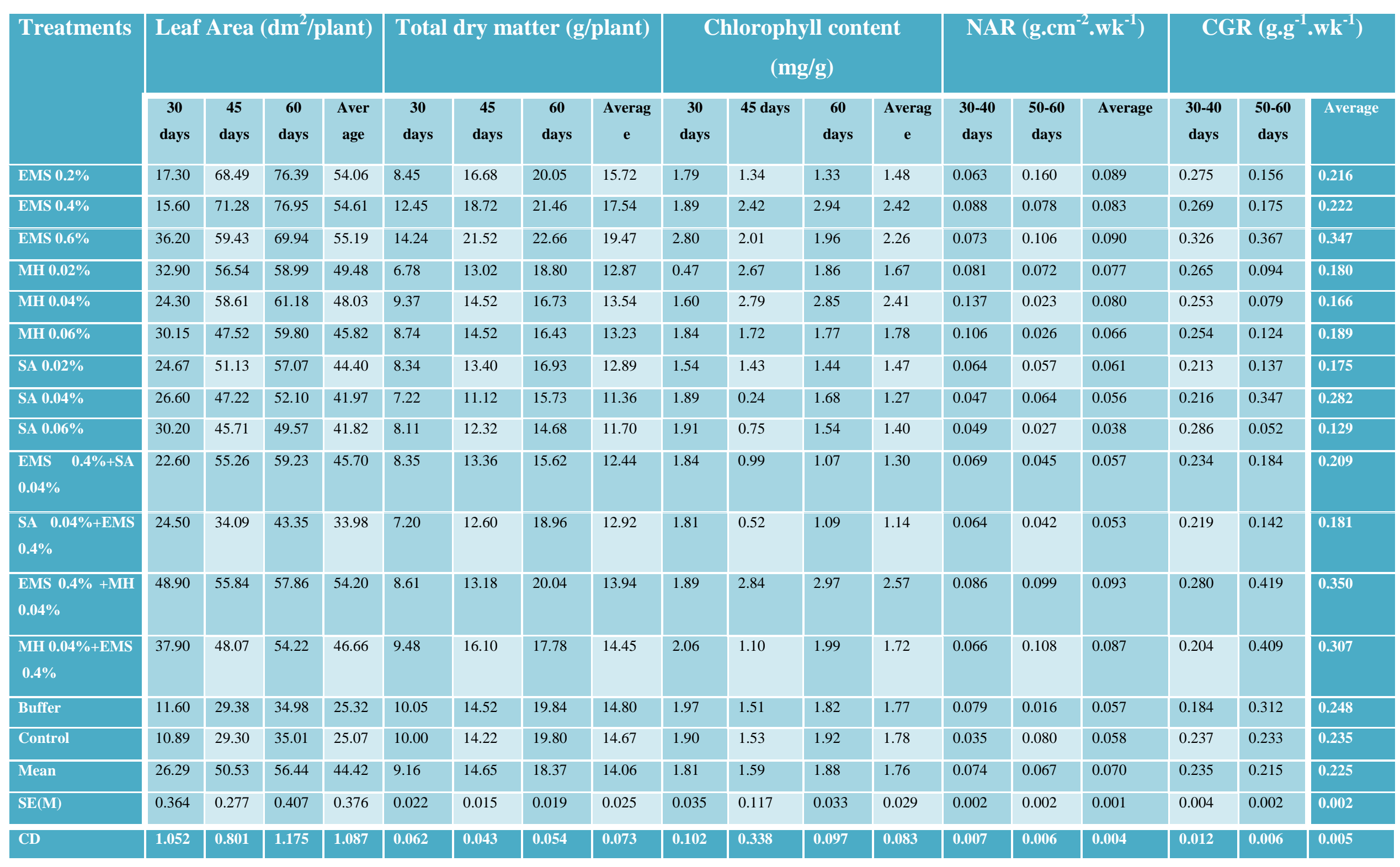


Total dry matter was also found to have increased over time and only EMS of $0.2 \%, 0.4 \%$ and $0.6 \%$ alone have shown increase as against buffer and control except $\mathrm{MH} 0.04 \%$ + EMS $0.4 \%$.

The chlorophyll content has shown different trends for different treatments. EMS 0.2\%, MH $0.06 \%$, SA $0.04 \%$, SA $0.06 \%$, EMS $0.4 \%+$ SA $0.04 \%$, SA $0.04 \%+$ EMS $0.4 \%$ and MH $0.04 \%$ + EMS $0.4 \%$ initially had higher chlorophyll content but later it has decreased. On an average it is observed that EMS 0.4\%, EMS 0.6\%, MH $0.04 \%$ and EMS $0.4 \%+$ MH $0.04 \%$ has shown highest chlorophyll content and are at par with each other.

NAR showed decreasing trend over time for treatments EMS 0.4\%,MH 0.02\%, MH 0.06\%, SA $0.02 \%$, SA $0.06 \%$, EMS $0.4 \%+$ SA $0.04 \%$ and SA $0.04 \%+$ EMS $0.4 \%$. But on an average NAR has increased as over control And Buffer. The maximum NAR was seen in combined treatment of EMS 0.4\% + MH 0.04\%.

The CGR was recorded to have decreased over time for all the treatments which may be due to the fact that during and after fruiting the crop growth rate decreases as the photosynthates have diverted for fruiting. Maximum CGR was recorded in EMS 0.6\% which is also the highest yielder and is at par with EMS $0.4 \%+\mathrm{MH}$ $0.04 \%$ with respect to Crop growth rate. All the treatments showed increase in yield over control and buffer except in treatment SA $0.06 \%$ which indicates that the mutagens had positive effect on the plant for increasing yield. The increase in yield depends on leaf area or photosynthesizing tissues, total respiring tissues or total biomass, photosynthetic efficiency as reflected by chlorophyll content, Net assimilation rate (NAR) and crop growth rate (CGR). EMS at $0.6 \%$ concentration had shown maximum increase in yield, was due to maximum leaf area $\left(55.19 \mathrm{dm}^{2} /\right.$ plant $)$, maximum total dry matter (19.44 g/plant) maximum crop growth rate $\left(0.347 \mathrm{~g} . \mathrm{g}^{-1} \cdot \mathrm{wk}^{-1}\right)$. The chlorophyll content and NAR (Net assimilation rate) were also significantly high for this treatment.

\section{References}

Akita, S. F. T., Laza, R. C., Blanco, L. C., Coronel, V. P., 1990, Physiological basis of rice yield potential improvement in the tropics. Proceedings of the International Congress of Plant Physiology 1:60-74.

Arnon, D. I., 1949, Copper enzymes in isolated chloroplasts, polyphenol oxidase in Beta vulgaris. L. Physiol., 24(I):1-15.

Augustine, J. J., Stevens, M. A., Briedenbach, R. W., Paige, D. F., 1975, Genotypic variation in Carboxylation of tomatoes, Pl. Physiol., 57:325-333.

Bhatt, R. M., Rao, N. K., Srinivasa, 1988, Carbon assimilation and dry matter partitioning in tomato cultivars. Veg. Sci., 15(1):21-30.

Das, K. P., Ghosh, B. K., Kar, M., Patro, B. B., 1997, Laboratory manual in plant physiology. Published by Professor and Head, Department of Plant Physiology, College of Agriculture, OUAT, Bhubaneswar.

Kharkwal, M. C., 2001, Induced mutations in chickpea (Cicer arietinum L.) Evaluation of micromutations. Indian J. Genet., 58: 61-68.

Masuda, M., Yuasa, T. and Murakami, K., 2005, Growth characters and genetic inheritance in tomato cv. 'First' mutant with short internodes induced by seed irradiation with ion beam; ScientificReports-of-the-Faculty-of-Agriculture,Okayama-University. 94: 25-29.

\section{How to cite this article:}

Tripathy, L., S.K. Dash and Pradhan, S.R. 2018. Effects of Chemical Mutagens on the PhysioChemical Traits of Tomato. Int.J.Curr.Microbiol.App.Sci. 7(04): 277-282.

doi: https://doi.org/10.20546/ijcmas.2018.704.031 